\title{
FAKTOR BRAND AWARENESS DAN PERSEPSI HARGA TERHADAP KEPUTUSAN PEMBELIAN PRODUK SEPATU MEREK NIKE TIRUAN DI HOME INDUSTRY CIKUPA TANGERANG
}

\author{
Ismayudin Yuliyzar \\ Universitas Muhammadiyah Tangerang \\ ismayudin_yulizar@yahoo.co.id
}

\begin{abstract}
Keyword
Brand Awareness, Price Perception, Purchasing Decisions.
\end{abstract}

\section{Abstract}

This study attempts to analyze the Brand Awareness Factor and Price Perception of Purchasing Decisions for Nike brand shoes at Cikupa Home Industry Tangerang. The sample of this study was 75 customer respondents from 300 customers. The method used is quantitative methods. Primary data collection was obtained from questionnaire collection. The analysis technique used is multiple linear regression analysis using Vesri SPSS 22 software. The results show that the partial variable of Brand Awareness (XI) is positively and significantly related to the Purchase Decision (Y). Price Perception (X2) has a positive and significant effect on Purchasing Decisions (Y). Simultaneously the Brand Awareness variable $(X I)$ and Price Perception (X2) considers positive and significant towards the Purchasing Decision (Y).

\section{PENDAHULUAN}

\section{Latar Belakang Masalah}

Perkembangan bisnis yang semakin berkembang saat ini membuat persaingan sangat ketat dan hampir pasti menuju ke persaingan tingkat tinggi (hypercompetition) baik di bidang produk maupun jasa. Dalam menghadapi persaingan tersebut perusahaan di tuntut harus mampu mempertahankan eksistensi usahanya di tengah masyarakat.

Produk Sepatu Merek Nike Tiruan atau biasa yang disebut dengan istilah produk $\mathrm{KW}$ semakin banyak beredar dimasyarakat hal ini disebabkan oleh gaya hidup masyarakat yang ingin menggunakan produk bermerek tetapi dengan harga yangt bisa dijangkau. Faktor lain yang juga semakin bertambahnya produk Sepatu Nike Tiruan terlihat dari semakin banyakanya pengrajin atau Home Industrypembuatan Sepatu merek Nike KW semakin bertebaran dimanamana hal ini terlihat dari banyaknya toko-toko kecil yang bermunculan menjual sepatu merek tersebut diatas. Peningkatan penduduk yang dibarengi dengan meningkatnya kebutuhan hidup memberikan lapangan pekerjaan atau bisnis baru. salah satu contoh bisnis yang mempunyai prospek yang baik adalah bisnis dalam bidang pembuatan Sepatu Nike tiruan. Oleh karena itu perusahaan harus memiliki strategi dan program pemasaran yang terdiri dari bauran pemasaran (product, price, place, promotion, people, prosess, dan physical evidence) harus didesain secara optimal untuk membangun ekuitas merek yang kuat serta bagaimana cara memuaskan agar konsumen tetap memiliki loyalitas terhadap produk yang dihasilkan. Komponen-komponen ini saling terkait satu sama lain dalam kelangsungan hidup suatu perusahaan. Secara khusus produk baik barang atau jasa yang di dapat oleh pelanggan tidak hanya untuk memenuhi kebutuhan konsumen tetapi manfaat dan nilai dari sesuatu yang ditawarkan.

Perusahaan atau produsen dapat meraih kemenangan dalam persaingan jika pilihan konsumen tidak akan berpindah, kemudian mampu membaca berbagai kondisi persaingan yang akan terjadi sebagai konsekuensi untuk bertahan dalam kancah persaingan di era globalisasi yang akan semakin mengarahkan kepada sistem perekonomian negara maupun mekanisme pasar yang pada akhirnya memposisikan pemasar untuk selalu mengembangkan strategi untuk merebut pangsa pasar.Oleh karena itu peranan dan perhatian terhadap merek saat ini menjadi faktor penting bagi strategi pemasaran untuk meningkatkan daya saing, menghasilkan nilai tambah dan 
mendorong penjualan. Pada dasarnya, merek adalah identitas product, service atau company yang mencerminkan nilai dan karakteristik, merek juga berperan sebagai payung representasi produk / jasa yang ditawarkan, dan dapat berperan sebagai perusahaan, dapat berperan sebagai orang, atau bahkan dapat berperan sebagai negara, perusahaan, orang dan symbol. Merek diperlukan sebagai pembeda (differentiation) dari produk sejenis lainnya sehingga tidak dianggap sekedar komoditas dan dapat dijadikan identitas dari produk sejenisnya yang dapat dibeli oleh konsumen. Selain itu, merek merupakan inti dari semua kegiatan pemasaran. Pasalnya produk tanpa merek tidak berarti apa-apa di mata konsumen, tetapi sebaliknya produk yang diberi merek akan memiliki nilai lebih tinggi di mata konsumen, merek yang di cintai oleh konsumen akan menyebabkan konsumen berbelanja, yakin, loyal dan percaya akan superioritasnya.

Seiring dengan persaingan yang ketat diantara produsen sepatu di tanah air maupun di eropa, dan gencarnya produk-produk sepatu yang bermunculan dari Negara lain seperti Nike, Adidas selaku produsen sepatu yang berasal dari Jerman selalu berusaha untuk menciptakan produk yang berkualitas dan selalu berusaha untuk tetap menjaga ekuitas merek agar tetap kuat dimata konsumen maupun perusahaan. Berbagai macam promosi yang agresif pun dilakukan baik dari segi kualitas produk, harga, desain produk, advertising, dan event-event untuk menunjang kenaikan penjualan, walaupun tidak segencar produk sepatu pesaing yang telah membius konsumen dengan berbagai macam negara di eropa yang memenangkan pangsa pasarnya dengan mempromosikan periklanan melalui sponsor pemain sepak bola.

Setiap merek yang di miliki oleh perusahaan akan menjadi kuat bila memiliki ekuitas merek yang kuat. Ekuitas merek yang kuat akan memberikan value, baik kepada konsumen maupun kepada pengrajin atau perusahaan. Sepatu merek Nike selalu membangun ekuitas merek yang di ciptakan tak lain hanya untuk memberikan kepuasan kepada konsumen yang nantinya akan menimbulkan loyalitas konsumen. Konsep hubungan ekuitas merek dengan loyalitas konsumen di mulai dari proses pengenalan merek yang akan menimbulkan kepercayaan oleh konsumen terhadap merek.

Merek (brand) yang begitu kuat akan sangat melekat pada konsumen, memberikan efek, menggambarkan secara luas dan secara aktif konsumen akan melakukan sharing mengenai pengalamannya menggunakan merek kepada orang lain. Tetapi jika persepsi terhadap kualitas keseluruhnya jelek maka sebesar apapun usaha perusahaan untuk menciptakan loyalitas terhadap produk cenderung tidak akan berhasil. Dengan adanya konsumen yang loyal, perusahaan akan memperoleh manfaat nilai yang tinggi dan dapat memanfaatkan premium price dan penerapan program pemasaran menjadi lebih efektif dan efisien, Karena memiliki konsumen yang loyal adalah tujuan akhir dari semua perusahaan dan merupakan salah satu yang menopang perusahaan tersebut untuk tetap hidup dan bertahan, bahkan semakin berkembang.

Saat ini kerajinan Home Industry produk sepatu Merek Nike tiruan di Cikupa Tangerang semakin meningkat perkembangan persaingan pangsa pasarnnya dengan perusahaan perusahaan sepatu yang menggunakan teknologi canggih, karena dengan harga yang sangat murah yang di jangkau oleh masayrakat menegah dan kebawah sesuai dengan penghasilannya, kerajinan sepatu Nike tituan ini pun melakukan pemasaran dengan memberikan harga promosi kepada pelanggannya seperti outlet atau toko toko dan pemilik lapangan futsal untuk di jadikan persediaan peminjaman sepatu tersebut, oleh karena itu kerajinan Home Industrysepatu Nike tiruan ini meneliti apa yang dibutuhkan masyarakat akan alas kaki tersebut dengan model varian yang berbeda.

Perkembangan kerajinan Home Industry sepatu Nike tiruan ini mengalami peningkatan tiap bulannya. Terbukti dengan tingkat pengunjung, pemesanan dan omset yang dihasilkan setiap bulanya mengalami peningkatan.

\section{Rumusan Masalah}

Berdasarkan latar belakang di atas, maka yang menjadi rumusan permasalahan dalam penelitian ini adalah:

I. Apakah terdapat pengaruh Brand Awarenesse terhadap keputusan Pembelian produk sepatu Nike tiruan di Home Industry Cikupa Tangerang?

2. Apakah terdapat pengaruh Persepsi Harga terhadap keputusan Pembelian produk sepatu Nike tiruan di Home Industry Cikupa Tangerang?

3. Apakah terdapat pengaruh Brand Awarenesse dan Persepsi Harga terhadap keputusan Pembelian produk sepatu Nike tiruan di Home Industry Cikupa Tangerang? 


\section{Definisi Brand}

American

Marketing Association

mendefinisikan merek sebagai "nama, istilah, tanda, lambang, atau desain, atau kombinasinya, yang dimaksudkan untuk mengidentifikasi barang atau jasa salah satu penjual atau kelompok penjual dan mendiferensiasikan dari para pesaing".

Ekuitas merek adalah nilai tambah yang diberikan pada produk dan jasa. Ekuitas merek dapat tercermin dalam cara konsumen berpikir, merasa, dan bertindak dalam hubungannya dengan merek, harga, pangsa pasar, dan profitabilitas yang diberikan merek bagi perusahaan. Pendekatan berbasis pelanggan memandang ekuitas merek dari perspektif konsumen (baik perorangan maupun organisasi). Prinsip dari ekuitas merek berbasis pelanggan adalah bahwa kekuatan merek terletak pada apa yang dilihat, dibaca, didengar, dipelajari, dipikirkan, dirasakan pelanggan tentang merek sepanjang waktu.

Menurut Henry Simamora(2013:543) mengatakan bahwa Kesadaran merek merupakan suatu ukuran seberapa banyak pelanggan potensial mengetahui sebuah merek. Strategi yang lazim dalam pemasaran dan periklanan adalah mempertinggi tingkat kesadaran merek.Pada hakekatnya, orang tidak akan membeli produk yang tidak mereka ketahui, namun keakrabannya dengan produk juga merupakan pengaruh pembelian yang kuat. Para pembeli jauh lebih merasa nyaman dengan produk yang dikenal dibandingkan dengan produk yang tidak dikenal.

Sementara menurut Aaker(2009:158) Brand Awareness sebagai tingkat kesadaran seseorang untuk mengenal bagian dari kategori produk. Hermawan Kertajaya (2010:122) Brand Awareness is the ability of a potential buyer to recognize or recall that a brand is a member of certain product category

Menurut Schiffman \& Kanuk (2007) persepsi adalah suatu prosesseorang individu dalam menyeleksi, mengorganisasikan, dan menterjamahkanstimulus-stimulus informasi yang datang menjadi suatu gambaran yangmenyeluruh. Persepsi mempunyai pengaruh yang kuat bagi konsumen. Salah satu faktor yang berpengaruh terhadap konsumen yaitu persepsi akan harga.

Dalam konteks pemasaran, menurut Kotler dan Garry Amstrong (2008)istilah harga dapat diartikan sebagai jumlah uang yang dibebankan untuk sebuah produk atau jasa atau jumlah nilai konsumen dalam pertukaran untuk mendapatkan manfaat dan memiliki atau menggunakan produk atau jasa. Menurut definisi tersebut, harga yang dibayar oleh pembeli sudah termasuk pelayanan yangdiberikan oleh penjual dan tidak dapat dipungkiri penjual juga menginginkan sejumlah keuntungan dari harga tersebut.

Persepsi harga merupakan kecenderungan konsumen untuk menggunakan harga dalam memberi penilaian tentang kesesuaian manfaat produk. Penilaian terhadap harga pada suatu manfaat produk dikatakan mahal, murah atau sedang. Dari masing-masing individu tidaklah sama, karena tergantung dari persepsi individu yang dilatar belakangi oleh lingkungan dan kondisi individu itu sendiri.

Teori lain yang terlkait dengan keputusan pembelian diantaranya adalah teori yang dikemukakan oleh Shciffman dan Kanuk (2000) dalam buku Etta Mamang Sangadji, Sopiah, (20I3) mendefinisikan keputusan pembelian sebagai pemilihan suatu tindakan dari dua pilihan alternatif atau lebih.

Sementara Setiadi(2003) mendefinisikan bahwa inti dari pengambilan keputusan konsumen adalah proses pengintegrasian yang mengkombinasikan pengetahuan untuk mengevaluasi dua perilaku alternatif atau lebih.

\section{METODOLOGI PENELITIAN}

Pada penelitian ini, penulis menggunakan pendekatan penelitian pendekatan kuantitatif. Pendekatan kuantitatif menurut Sugiyono (2009 : 7) Penelitian kuantitatif merupakan "Metode penelitian yang berlandaskan pada filsafat positivisme, yang digunakan untuk meneliti pada populasi atau sampel tertentu, pengumpulan data menggunakan instrument penelitian, analisis data bersifat statistik dengan tujuan untuk menguji hipotesis yang telah ditetapkan". Dimana akan meneliti secara umum tentang pengaruh marketing mix terhadap keputusan menabung.

\section{Metode Deskriptif Analisis}

Menurut Sugiyono (2009:21) Penelitian deskripif adalah "Jenis penelitian yang mengambarkan apa yang dilakukan oleh perusahaan berdasarkan fakta-fakta yang ada untuk selanjutnya diolah menjadi data". Data tersebut kemudian dianalisis untuk memperoleh kesimpulan, dalam penelitian deskriptif digunakan untuk mengambarkan mengenai faktor individu dan pengambilan keputusan. Suatu metode penelitian untuk membuat gambaran mengenai situasi atau kejadian. 
Metode Analisis Statistik

Analisa regresi sederhana

Persamaan regresi sederhana dapat dirumuskan sebagai berikut :

$\ddot{Y}=a+b x$

Sumber : Riduwan, (2010: 178)

Dimana :

$Y=$ Variabel terikat

$\mathrm{X}=$ Variabel bebas

$\mathrm{a}=$ nilai konstanta harga $Y$ jika $X=0$

$\mathrm{b}=$ nilai arah sebagai penentu ramalan prediksi yang menunjukkan nilai kenaikan atau penurunan variabel $Y$.

$$
\begin{aligned}
& \mathrm{a}=\frac{\sum \mathrm{Y}-\mathrm{b} \cdot \sum \mathrm{X}}{n} \\
& \mathrm{~b}=\frac{\left(n \cdot \sum \mathrm{X} \mathrm{Y}\right)-\left(\sum \mathrm{X} \sum \mathrm{Y}\right)}{n \cdot \sum \mathrm{X}^{2}-\left(\sum \mathrm{X}\right)^{2}}
\end{aligned}
$$

\section{Analisis Regresi Linear Berganda}

Analisis regresi linear berganda digunakan untuk menganalisa pengaruh beberapa variabel bebas terhadap variabel terikat secara bersamasama.Alat yang digunakan untuk menguji dengan menggunakan program SPSS. Dalam hubungan dengan penelitian ini, variabel bebas adalah (XI), Brand Awareness (X2), Persepsi harga sedangkan variabel terikat adalah keputusan Pembelian (Y).

Berikut ini rumus regresi linear berganda:

$$
\mathrm{Y}=\alpha+\beta_{1} \mathrm{X}_{1}+\beta_{2} \mathrm{X}_{2}+\mathrm{e}
$$

Sumber : Toni Wijaya (2009:91)

Dimana:

$Y=$ Variabel $Y$ ( Keputusan

Pembelian )

$\alpha=$ Konstanta persamaan regresi

$\beta_{1}=$ Koefisien regresi variabel $X I$

$\beta_{2}=$ Koefisien regresi variabel $X 2$

$X I=$ Variabel $X I$ (Brand Awareness)

$\mathrm{X} 2=$ Variabel $\mathrm{X} 2$ (Persepsi harga)

\section{Koefisien Korelasi Sederhana ( $r$ )}

Koefisien korelasi sederhana digunakan untuk menilai tingkat hubungan antara variabel bebas $(\mathrm{X})$ dan variabel tidak bebas $(\mathrm{Y})$.

\section{HASIL PENELITIAN DAN PEMBAHASAN}

\section{Karakteristik Responden}

Para responden penelitian akan dilihat karakteristiknya menurut umur, pekerjaan, dan jenis kelamin agar dapat mengetahui gambaran secara umum para konsumen yang membeli Sepatu Nike tiruan Home Industry Cikupa Tangerang.

\section{Umur Responden}

Adapun data mengenai umur responden konsumen Sepatu Nike tiruan Home Industry Cikupa Tangerang adalah sebagai berikut:

\section{Tabel I. Umur Responden}

\begin{tabular}{|c|c|c|c|}
\hline No & Keterangan & Jumlah & Presentase \\
\hline 1 & $17-20$ tahun & 8 & $10,50 \%$ \\
\hline 2 & $21-25$ tahun & 23 & $30,50 \%$ \\
\hline 3 & $26-30$ tahun & 30 & $40 \%$ \\
\hline 4 & $>30$ tahun & 14 & $19 \%$ \\
\hline \multicolumn{2}{|c|}{ Jumlah } & 75 & $100 \%$ \\
\hline
\end{tabular}

Sumber : Data primer yang diolah, 2015

\section{Pekerjaan Responden}

Adapun data mengenai umur responden konsumen Sepatu Nike tiruan Home Industry Cikupa Tangerang adalah sebagai berikut:

Tabel 2. Pekerjaan Responden

\begin{tabular}{|c|l|c|c|}
\hline No & \multicolumn{1}{|c|}{ Pekerjaan } & Jumlah & Presentase \\
\hline I & PNS/TNI/POLRI & 10 & $13 \%$ \\
\hline 2 & Swasta/Wiraswasta & 17 & $22,50 \%$ \\
\hline 3 & Pelajar/Mahasiswa/i & 34 & $45,50 \%$ \\
\hline 4 & Pensiunan & 9 & $12 \%$ \\
\hline 5 & Lain-Lain & 5 & $7 \%$ \\
\hline \multicolumn{2}{|c|}{ Jumlah } & 75 & $100 \%$ \\
\hline
\end{tabular}

Sumber : Data primer yang diolah, 2015

Dalam penelitian ini jumlah responden yang termasuk dalam kategori pekerjaan antara pelajar/mahasiswa lebih banyak (45,5\%) dibanding jumlah responden pada kategori pekerjaan lainnya. Sedangkan yang paling sedikit menjadi responden adalah kategori Lain-lain $(7 \%)$.

\section{Teknik Analisis Data}

I. Uji Validitas dan Reliabilitas Instrumen

Untuk menguji validitas dan reliabilitas instrumen, penulis menggunakan analisis dengan SPSS. Untuk tingkat validitas dilakukan uji signifikansi dengan membandingkan nilai $r$ hitung dengan nilai $r$ tabel. Untuk degree offreedom (df) $=\mathrm{n}-\mathrm{k}$ dalam hal ini $\mathrm{n}$ adalah jumlah sampel dan $\mathrm{k}$ adalah jumlah konstruk. Pada penelitian ini besarnya $\mathrm{df}$ dapat dihitung 75-2 atau $\mathrm{df}=73$ dengan alpha 0,05 didapat $r$ tabel 0,227 ; jika $r$ 
hitung lebih besar dari $r$ tabel dan nilai $r$ positif, maka butir pertanyaan tersebut dikatakan valid.

Hasil dari pengolahan data diketahui bahwa seluruh item pada variabel Brand Awareness(XI), Persepsi Harga (X2), Keputusan Pembelian $(Y)$ menghasilkan nilai $r$ hitung yang lebih tinggi dari 0,5 dengan tingkat signifikan lebih kecil dari 0,05. Hasil ini menunjukkan bahwa seluruh item yang ada dalam variabel Brand Awareness, Persepsi Harga, dan Keputusan Pembelian mempunyai nilai diatas 0,227 dan dinyatakan valid sedangkan untuk uji reliabilitas.

Berdasarkan hasil uji reliabilitas diatas dari variabel Brand Awareness, Persepsi Harga dan Keputusan Pembelian dapat diketahui (Cronbach's Alpha) tiap variabel. Untuk Brand Awareness (XI) nilai Cronbach's Alpha sebesar 0,986, Persepsi Harga (X2) sebesar 0,984 dan Keputusan Pembelian (Y) sebesar 0,962, karena nilai dari ketiga variabel tersebut $>0,60$ maka dapat disimpulkan bahwa alat ukur dalam penelitian ini adalah reliabel.

\section{Analisis Regresi Sederhana}

Analisis regresi sederhana adalah proses mengestimasi (menaksir) sebuah fungsi anatara variabel independent $(X)$ dengan variabel dependent $(Y)$. Untuk menguji ada tidaknya pengaruh variabel $(X)$ terhadap variabel $(Y)$, maka dilakukan analisis statitik dengan menggunakan regresi linier sederhana.

Dalam melakukan analisis Brand Awareness $(\mathrm{XI})$, berpengaruh terhadap keputusan pembelian ( $\mathrm{Y})$ digunakan analisis regresi sederhana.

Berdasarkan hasil analisis regresi berganda pada tabel di atas diperoleh koefisien untuk variabel bebas $X I=8,75$, konstanta sebesar 4,977 sehingga model persamaan regresi yang diperoleh adalah :

$$
\begin{aligned}
& Y=4,977+8,75 X I \\
& \text { Di mana: } \\
& Y=\text { Keputusan Pembelian } \\
& X I=\text { Brand Awareness }
\end{aligned}
$$

Dan berdasarkan hasil analisis regresi untuk variabel $X 2$ diperoleh koefisien untuk variabel bebas $X 2=0,946$, konstanta sebesar I,494 sehingga model persamaan regresi yang diperoleh adalah :

$$
Y=1,494+0,946 \times 2
$$

Di mana:

$$
\begin{aligned}
& Y=\text { Keputusan Pembelian } \\
& X 2=\text { Persepsi Harga }
\end{aligned}
$$

Berdasarkan hasil uji regresi di atas dapat disimpulkan bahwa variabel independen yang mempunyai pengaruh positif paling besar terhadap keputusan pembelian adalah pada variabel persepsi harga yang dimiliki kerajinan Sepatu Nike Tiruan Home Industry, sedangkan variabel yang paling kecil dalam hal mempengaruhi keputusan pembelian pada produk Sepatu Nike TiruanHome Industry adalah pada variabel Brand Awarennes.

Untuk hasil uji regresi berganda diperoleh koefisien untuk variabel bebas $X I=0,459, \times 2=$ 0,485 , konstanta sebesar 1,947 sehingga model persamaan regresi yang diperoleh adalah:

$$
\begin{aligned}
& Y=1,947+0,459 \times 1+0,485 X 2 \\
& \text { Di mana: } \\
& Y=\text { keputusan pembelian } \\
& X I=\text { variabel Brand Awareness } \\
& X 2=\text { variabel Harga kualitas }
\end{aligned}
$$

Dari persamaan regresi di atas dapat diartikan sebagai berikut:

Konstanta sebesar I,947 menyatakan bahwa, jika variabel independen (XI) Brand Awarenessnilainya adalah 0 , maka keputusan pembelian konsumen pada produk sepatu Nike tiruan Home Industry adalah sebesar 1.947

Koefisien regresi XI Brand Awareness mempengaruhi keputusan pembelian sebesar 0,459 atau berpengaruh positif yang artinya jika Brand Awarenessditingkatkan $1 \%$ saja, maka keputusan pembelian akan meningkat sebesar 0,459. Sebaliknya, jika Brand Awarenessditurunkan I\% saja, maka keputusan pembelian akan menurun sebesar 0,459.

Sedangkan untuk Koefisien regresi $\times 2$ (variable persepsi harga) mempengaruhi keputusan pembelian sebesar 0,485 atau berpengaruh positif yang artinya jika persepsi hargaditingkatkan I\% saja, maka keputusan pembelian akan meningkat sebesar 0,485 Sebaliknya, jika Persepsi Harga diturunkan 1\% saja, maka keputusan pembelian akan menurun sebesar 0,485.

Hasil olahan statistik untuk uji koefisien korelasi (R) artinya bahwa kedua variabel bebas mempunyai hubungan yang cukup kuat yaitu sebesar 0,990 sedangkan besarnya pengaruh variabel Brand Awarness dan Persepsi harga terhadap variabel keputusan pembelian sepatu Nike tiruan dapat dijelaskan dari hasil Koefisien 
Determinasi yaitu sebesar $98,1 \%$ sedang yang I,9\% sisanya dijelaskan variabel lain yang tidak dimasukkan dalam model ini (tidak diteliti). Hasil uji koefisien determinasi tersebut memberikan makna, bahwa masih terdapat variabel independen lain yang mempengaruhi keputusan pembelian konsumen walaupun nilainya tidak signifikan.

\section{PENUTUP}

Berdasarkan permasalahan dan pembahasan mengenai hubungan yang terjadi antara variableBrand Awareness dan Persepsi Harga terhadap keputusanpembelianpadaproduk Sepatu Nike tiruanHome IndustryCikupaTangerang, maka dapat ditarik kesimpulan sebagai berikut:

I. Berdasarkan hasil pengujian SPSS, secara parsial terdapat pengaruh yang signifikan Brand Awareness terhadap keputusan pembelian produk sepatu Nike tiruan Home Industry Cikupa Tangerang, hal dapat dilihat dari hasil uji $t$ dengan $t$ hitung table, sebesar $(36.197>1,99)$ dengan taraf signikansi $0,000<0,5$, maka $\mathrm{HO}$ ditolak, artinya bahwa Brand Awareness secara parsial berpengaruh terhadap keputusan pembelian.

2. Berdasarkan hasil pengujian SPSS, secara parsial terdapat pengaruh yang signifikan persepsi harga terhadap keputusan pembelian produk sepatu Nike tiruan Home Industry Cikupa Tangerang, hal dapat dilihat dari hasil uji $t$ dengan $t$ hitung table, sebesar $(35.625>1,99)$ dengan taraf signikansi $0,000<0,5$, maka $\mathrm{HO}$ ditolak, artinya bahwa persepsi harga secara parsial berpengaruh terhadap keputusan pembelian.

3. Berdasarkan hasil pengujian SPSS, secara simultan atau secara bersama-sama terdapat pengaruh yang signifikan Brand Awarenessdan persepsi harga terhadap keputusan pembelian produk sepatu Nike tiruanHome Industry Cikupa Tangerang, hal dapat dilihat dari hasil uji $f$ dengan $f_{\text {table, }}$ sebesar $(1866.470>2,73)$ dengan taraf signikansi $0,000<0,5$, maka HO ditolak, artinya bahwa Brand Awarenessdan persepsi harga secara simultan atau secara bersamasama berpengaruh terhadap keputusan pembelian.
Arifin, Antoni Ludfi, dkk., 20I5. Building Personal Brand Equity,Jakarta,GramediaPustakaUtama.

Buchari Alma, 2013.

ManajemenPemasarandanManaje menjasaBandung

DanangSunyoto,

2012.Dasar-

DasarManajemenPemasaran

(konsep, strategi, dankasus). Yogyakarta : Tri Admojo

Hasan, Ali, 20I3.Marketing dan Kasus-kasus Pilihan, Jakarta: CAPS (Center for Academic Publishing Service.

HermawanKertajaya, 2010, Brand Operation, Erlangga, Jakarta.

Hamidi, Arsyad, dkk 2014. Pengaruh Ekuitas Merek terhadap Keputusan Pembelian : Survei pada Konsumen Sepeda Motor Merek Honda di Dealer PT. Nusantara Surya. Jurnal Administrasi Bisnis.(Vol. 10, no. I, Mei)

Irwanti, Ika 20l3. Analisis Pengaruh Brand Equity terhadap Keputusan Pembelian pada Konsumen POND'S di Kota Surabaya. Jurnal Manajemen. (Vol. IO, no. I, Juni)

Kotler, Philip dan Keller, Kevin Lane, 2010.

Manajemen Pemasaran, Edisi I 3 jilid

I Jakarta: Erlangga.

Kertajaya, Hermawan, 20I0. Mark Plus Basic, Jakarta:Esensi Erlangga Group.

Sangadji, Etta, Mamang, 2013. Perilaku Konsumen, Yogyakarta, PenerbitANDI.

Sugiyono.20I I.Metodepenelitiankuantitati, Kualitatifdan R\&D (cetakanke 14).Bandung Alfabeta. 